\title{
СТАНДАРТИЗАЦІЯ ПОЧАТКОВОЇ ОСВІТИ ДІТЕЙ ІЗ ТЯЖКИМИ ПОРУШЕННЯМИ МОВЛЕННЯ В УМОВАХ НОВОЇ УКРАЇНСЬКОЇ ШКОЛИ
}

\begin{abstract}
У статті розкрито загальні тендениії розроблення та впровадження стандартизації початкової освіти дітей із тяжкими порушеннями мовлення в умовах Нової української иколи. Проаналізовано табличну структуру освітніх нормативних документів, згідно з якими, з урахуванням особливостей психофізичного, зокрема мовленнєвого, розвитку здобувачів початкової освіти, здійснюється розроблення відповідного стандарту. Виокремлено та схарактеризовано сім взаємопов'язаних напрямів здійснення освітнього процесу, зумовлених патогенезом мовленнєвих порушень, репрезентовано загальні умови його успішної реалізачії.
\end{abstract}

Ключові слова: стандартизація, діти з тяжкими порушеннями мовлення, Нова украӥнська школа.

Julia RIBTSUN, orcid.org/0000-0002-2672-3704

Candidate of Pedagogical Sciences, Senior Researcher, Senior Researcher, Department of Speech Therapy, Institute of Specialized Pedagogics and Psychology named after Nicholas Yarmachenko

National Academy of Sciences of Ukraine (Kyiv,Ukraine)logojuli@i.ua

\section{STANDARDIZATION OF PRIMARY EDUCATION OF CHILDREN WITH SERIOUS LOSSES IN THE CONDITIONS OF THE NEW UKRAINIAN SCHOOL}

The article describes the issues of standardization of the educational process. The relevance is due to difficulties in teaching children with severe speech disorders. Particularly important is the qualitative transition from preschool to school age. Speech disorders affect the development of perception, attention, memory, thinking, emotions, and children's personality. Schoolchildren are trained in an inclusive education. The state standard of primary education for children with disabilities was developed in 2013. In 2018, the State Standard of General Primary Education appeared. Therefore, there is a need to develop a new standard for children with disabilities. Creating a new educational standard is possible when analyzing regulatory documents. Regulatory educational documents are standard and programs. The standard has a basic curriculum. The basic curriculum has four options. Two are suitable for children with speech disorders. The first option is for special schools and classes. The second option is for general schools. For children with disabilities provided correctional work. Training is distributed along educational lines. They are compiled in separate academic subjects.

Educational programs are based on the standard. Standard and programs are made in the form of tables. Each table consists of two columns. The columns in each regulatory document are different. But their content is almost the same. It is on the basis of the general standard and programs that a special standard is drawn up. Primary education of children with speech disorders is built in the form of a dialogue. Therefore, developed guidelines for teachers. Teachers of inclusive resource centers can use the same recommendations. We have proposed requirements for mandatory learning outcomes in primary school. These results will form the basis of further education in high school. We have identified seven interrelated educational areas: "Speech Development», "Physical and Speech Development», "Cognitive and Speech Development», "Emotional and Value Development», "Creative and Speech Development», "Social and Communication Development», "Educational and speech activity». The directions of education are due to the pathogenesis of speech disorders. The general conditions of effective implementation of the educational process are disclosed.

Key words: standardization, children with severe speech disorders, New Ukrainian school. 
Постановка проблеми. Дитина, 3 iii індивідуальними особливостями, психофізичними можливостями, потребами та інтересами виступає в освітньому процесі суб'єктом діяльності та спілкування. Рушійними силами психічного розвитку дитини є зумовлена генотипом ії̈ природна основа, а також існуючі суперечності між психічними особливостями (внутрішні умови психічного розвитку) та соціальним середовищем (зовнішня умова). Перехід дитини старшого дошкільного віку до здобувача початкової освіти характеризується появою нової ситуації розвитку, вдосконаленням базових особистісних якостей, що створюють міцну психофізіологічну основу для навчання в школі. Саме для того, щоб цей перехід відбувався найбільш гармонійно, а наступність була перспективною, перший рівень освіти, як завершений іiі етап, має два цикли: адаптаційноігровий (1-2 класи) та основний (3-4 класи), впродовж яких учні під керівництвом дорослих навчаються виконувати прості завдання в типових ситуаціях у чітко визначеній сфері діяльності в умовах Нової української школи (Про затвердження Державного стандарту: 9).

$\mathrm{У}$ дітей із тяжкими порушеннями мовлення (далі - ТПМ) такий перехід є значно уповільненим i своєрідним, що зумовлено практичною відсутністю (обмеженістю) мовних засобів спілкування, специфічними особливостями пізнавальної, рухової та особистісної сфер, а саме: 1) загальною емоційною виснажуваністю; 2) ослабленістю мотиваційної основи будь-якої діяльності; 3) недостатністю прояву вольових зусиль; 4) деякою фрагментарністю у сприйманні зорової та вербальної інформації; 5) моторною незграбністю; 6) недосконалістю мнестичних, основних мисленнєвих операцій; 7) дефіцитом уваги до звукового, лексичного, морфологічного, граматичного та синтаксичного оформлення мовлення; 8) порушеннями психологічних операцій зорової, слухової, кінетичної, кінестетичної модальностей; 9) недостатньою сформованістю загальних лінгвістичних уявлень, аграматизмами, збідненістю словникового запасу; 10) незрілістю вимовних і звукорозрізнювальних навичок; 11) труднощами у встановленні причиннонаслідкових зв'язків і розумінням порівняльних, пасивних, інвертованих, складних синтаксичних конструкцій тощо (Е. Данілавічютє, В. Ільяна, Р. Лалаєва, Р. Левіна, Ю. Рібцун, С. Соботович, В. Тарасун, В. Тищенко, Л. Трофименко, Н. Чередніченко та ін.). Саме тому організація та проведення освітнього процесу потребує відповідної стандартизації, як на рівні дошкільної, так і початкової освіти дітей із тяжкими порушеннями мовлення (Рібцун, 2017).

Аналіз досліджень. Існуючий Державний стандарт початкової загальної освіти дітей 3 особливими освітніми потребами датується 2013 роком (Постанова Кабінетів Міністрів України № 607 від 21.08.2013 р.), адже був розроблений на основі Державного стандарту початкової загальної освіти ще у 2011 р. (Постанова Кабінетів Міністрів України № 462 від 20.04.2011р.), тому є застарілим і не відповідає сучасним вимогам (Про затвердження Державного стандарту: 5). Це у свою чергу свідчить про необхідність розроблення нового базового інструмента реалізації конституційного права на освіту дітей $з$ особливими освітніми потребами, зокрема 3 тяжкими порушеннями мовлення. Водночас зі значним розширенням мережі закладів 3 інклюзивною формою навчання, де здобувають освіту у т. ч. й діти 3 ТПМ (Про внесення змін, 2018: 8), функціонуванням інклюзивно-ресурсних центрів (Про затвердження Положення: 7), розробленням корекційнорозвиткових програм (Ю. Рібцун, Л. Трофименко, 2018) має повністю змінитися структура та змістове наповнення стандарту, в якому на перший план виходитиме багатофункціональність, гнучкість і комплексність форм і методів роботи 3 учнями зазначеної категорії.

Саме тому метою статті $\epsilon$ висвітлення загальних тенденцій щодо розроблення стандарту початкової освіти дітей із тяжкими порушеннями мовлення.

Виклад основного матеріалу. Зважаючи на те, що учні з ТПМ здобувають цензову освіту, тобто засвоюють той обсяг знань, що відповідає державному рівню обов'язкових вимог, доцільно проаналізувати структуру Державного стандарту початкової загальної освіти та співставити іiї 3 типовими освітніми програмами для закладів загальної середньої освіти, розроблених під керівництвом О. Савченко та Р. Шияна, затвердженими на рівні Міністерства освіти й науки України, адже саме на його основі відбувається розроблення закладами освітніх програм (Про загальну середню освіту; Про затвердження Положення; Про схвалення Концепції).

Державний стандарт містить Базовий навчальний план початкової освіти, в якому для здобуття освіти дітьми з ТПМ підходять два найпоширеніші варіанти: 1) для спеціальних закладів (класів) загальної середньої освіти 3 українською мовою навчання дітей 3 особливими освітніми потребами - логопедичні класи та школи для дітей із тяжкими порушеннями мовлення; 2) для закладів 
загальної середньої освіти 3 українською мовою навчання - за умов інклюзивного навчання. Незважаючи на те, що інваріантний складник базового навчального плану є обов'язковим для всіх закладів незалежно від їх підпорядкування і форм власності, що здійснюється з метою підтримання цілісності освіти, в кожній освітній галузі передбачено проведення обов'язкової корекційнорозвиткової роботи, змістове наповнення якої зумовлене станом психофізичного розвитку учнів 3 особливими освітніми потребами (Про затвердження Державного стандарту; Про схвалення Концепції). Змістові лінії кожного нормативного документа (стандарту та програм) реалізуються відповідно до освітньої галузі (див. табл. 1).

Як бачимо, назви освітніх галузей стандарту і програм переважно збігаються, окрім інтеграції у типовій освітній програмі О. Савченко. Для зручності викладу і стандарт, і освітні програми складені у вигляді таблиць, тож проаналізуємо табличну структуру нормативних документів (див. табл. 2).

У програмі Р. Шияна додатково виокремлений також пропонований зміст, що окреслює той навчальний матеріал, на підставі якого формуватимуться очікувані та відповідні обов'язкові результати навчання. Отже, незважаючи на те, що в різних освітніх документах назви колонок різ- няться чи переставлені місцями, загальна тенденція викладу залишається стійкою та збігається 3 концепцією Нової української школи, яку можна брати за основу складання стандарту початкової освіти дітей із тяжкими порушеннями мовлення.

Реалізація змісту будь-якої освітньої галузі, в залежності від навчального середовища, в якому перебуває дитина з ТПМ, можлива лише на засадах тісного співробітництва команди фахівців, як закладу загальної середньої, спеціальної освіти, так і реабілітаційного чи інклюзивно-ресурсного центрів (Про затвердження Положення; Рібцун, 2018). Наприклад, у мистецькій галузі спів та гра на музичних інструментах може поєднуватися із заняттями інструктора 3 фізичної культури (логоритміка); інтерпретація творів мистецтва - здійснюватися на заняттях 3 учителем-логопедом; зображувальна, театралізована діяльність, інсценізації - реалізовуватись на заняттях із практичним психологом тощо. Додаткові навчальні засоби, зокрема, комп'ютери, проектори та інтерактивні дошки можуть слугувати для полегшення розгляду, наприклад, репродукцій картин чи збільшення їхніх окремих фрагментів; мікрофони та навушники, «дзеркала, що розмовляють», дозволять зробити спів або виконання вокальних вправ більш правильним і чітким. Стандартизація

Таблиця 1

Освітні галузі нормативних документів

\begin{tabular}{|c|c|c|c|}
\hline \multirow{11}{*}{ 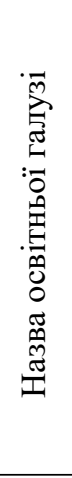 } & \multirow{2}{*}{ Державний стандарт } & \multicolumn{2}{|c|}{ Типова освітня програма } \\
\hline & & Р. Шияна & О. Савченко \\
\hline & \multicolumn{2}{|c|}{ Мовно-літературна } & Мовно-літературна Іншомовна \\
\hline & \multicolumn{3}{|c|}{ Математична } \\
\hline & \multicolumn{2}{|c|}{ Природнича } & \multirow{3}{*}{ Я досліджую світ } \\
\hline & \multicolumn{2}{|c|}{ Соціальна і здоров’язбережувальна } & \\
\hline & \multicolumn{2}{|c|}{ Громадянська та історична } & \\
\hline & \multicolumn{3}{|c|}{ Технологічна } \\
\hline & \multicolumn{3}{|c|}{ Інформатична } \\
\hline & \multicolumn{3}{|c|}{ Мистецька } \\
\hline & \multicolumn{3}{|c|}{ Фізкультурна } \\
\hline
\end{tabular}

Таблиця 2

Таблична структура нормативних освітніх документів

\begin{tabular}{|c|l|l|}
\hline Назва документа & \multicolumn{1}{|c|}{$\begin{array}{c}\text { Назва першої колонки } \\
\text { та ї̈ дефініція }\end{array}$} & $\begin{array}{c}\text { Назва другої колонки } \\
\text { та ї̈ дефініція }\end{array}$ \\
\hline $\begin{array}{c}\text { Державний } \\
\text { стандарт }\end{array}$ & $\begin{array}{l}\text { Загальні результати навчання здобувачів } \\
\text { освіти - стислі вимоги до знань школярів }\end{array}$ & $\begin{array}{l}\text { Обов’язкові результати навчання здобувачів } \\
\text { освіти - розгорнуті вимоги, що є основою } \\
\text { для подальшого навчання учнів }\end{array}$ \\
\hline $\begin{array}{c}\text { Типова освітня } \\
\text { програма } \\
\text { О. Савченко }\end{array}$ & $\begin{array}{l}\text { Очікувані результати навчання здобувачів } \\
\text { освіти - розгорнуті вимоги до конкретних } \\
\text { знань учнів }\end{array}$ & $\begin{array}{l}\text { 3міст навчання - стисле змістове наповне- } \\
\text { ння що відповідає окремому навчальному } \\
\text { предмету чи інтегрованому курсу }\end{array}$ \\
\hline $\begin{array}{c}\text { Типова освітня } \\
\text { програма } \\
\text { Р. Шияна }\end{array}$ & $\begin{array}{l}\text { Обов'язкові результати навчання - стислий } \\
\text { загальний обсяг навчального матеріалу }\end{array}$ & $\begin{array}{l}\text { Очікувані результати навчання - розгорнуті } \\
\text { завдання, які має реалізувати вчитель }\end{array}$ \\
\hline
\end{tabular}


передбачає оптимізацію початкової освіти школярів із ТПМ через реалізацію діалогової взаємодії в діаді «педагог-учень» шляхом надання певних рекомендацій педагогам 3 урахуванням загальних (за змістовими лініями) та обов'язкових результатів навчання, які складають основу для подальшого опанування навчальними предметами загальної середньої освіти (Рібцун, 2018). Запропоновані рекомендації носять оглядовий, загальнорозвивальний характер і $є$ своєрідною підготовчою роботою, що утворює дієвий базис подальшого навчання учнів із тяжкими порушеннями мовлення в умовах Нової української школи.

У кожній змістовій лінії передбачено реалізацію семи наскрізних взаємопов'язаних напрямів, зумовлених патогенезом мовленнєвих порушень: «Мовленнєвий розвиток» (МР), «Фізично-мовленнєвий розвиток» (ФМР), «Когнітивно-мовленнєвий розвиток» (КМР), «Емоційно-ціннісний розвиток» (ЕЦР), «Творчо-мовленнєвий розвиток» (ТМР), «Соціально-комунікативний розвиток» (СКР), «Навчально-мовленнєва діяльність» (НМД). Напрям «Мовленнєвий розвиток» втілюється через фонетичний, фонематичний, лексичний, морфологічний і синтаксичний коди на рівні усного та писемного мовлення. Напрям «Фізичномовленнєвий розвиток» реалізуєтьсяу смисловому, оральному, локомоторному, соматопросторовому, графічному, конструктивно-просторовому, мануальному, пальцевому, артикуляційному, мімічному праксисі. Напрям «Когнітивно-мовленнєвий розвиток» передбачає вдосконалення основних психічних процесів: а) тактильного, слухового, предметного, кольорового, лицьового та графічного зорового, зорово-просторового, сомато-просторового гнозису; б) модально-специфічних видів уваги (зорової, слухової, рухової, інтелектуальної); в) зорової, слухової та рухової пам'яті; г) конструктивного, наочно-образного, просторово-часового, вербально-логічного мислення. Напрям «Емоційно-иіннісний розвиток» спрямований на усвідомлення духовних цінностей, вироблення адаптивних форм поведінки, конструктивного керування своїми емоційними станами, розвиток вольових якостей. Напрям «Творчо-мовленнєвий розвиток» передбачає стимулювання ініціативності, розкриття творчого потенціалу учнів, їхніх нахилів і здібностей через різні види мистецтва та трудової діяльності. Напрям «Соuіально-комунікативний розвиток» акцентує увагу на зміні співвідношення соціальних детермінант (сім'я - школа - клас - друзі), розширенні вербально-комунікативних зв'язків учнів із соціальним середовищем, збагаченні їхнього суспільного досвіду, виробленні вміння працювати самостійно і в групі, вирішувати виниклі проблеми, логічно обгрунтовувати свою думку. Провідний вид діяльності в шкільному віці обумовив виділення напряму «Навчально-мовленнєва діяльність», що включає сукцесивний і симультанний способи сприймання нової інформації, здатність iii розуміти, узагальнювати, адекватно застосову-

Таблиця 3 Діалогова взаємодія педагогів та учнів початкових класів із тяжкими порушеннями мовлення

\begin{tabular}{|c|c|c|}
\hline \multirow[t]{2}{*}{ Рекомендації педагогам щцоо підвицення ефективності освітнього процесу } & \multicolumn{2}{|c|}{$\begin{array}{c}\text { Результати навчання } \\
\text { здобувачів освіти }\end{array}$} \\
\hline & загальні & обов'язкові \\
\hline \multicolumn{3}{|l|}{ Змістова лінія «Художньо-практична діяльність» } \\
\hline $\begin{array}{l}\text { Здійснювати постановку діафрагмального дихання, виробляти цілеспрямований } \\
\text { видихуваний повітряний струмінь. (МР, ФМР) } \\
\text { Спонукати до вироблення співацької постави. (ФМР) } \\
\text { Удосконалювати вміння виконувати вправи артикуляційної, мімічної, голосової гім- } \\
\text { настики, психогімнастики, вправи на розвиток слухової уваги та пам'яті, основних } \\
\text { мисленнєвих операцій. (КМР, ФМР, МР, ЕЦР) } \\
\text { Здійснювати постановку, автоматизацію та диференціацію звуків української мови. (МР) } \\
\text { Вчити слухати і чути музичний супровід; співати, контролюючи темп, ритм, } \\
\text { гучність виконання. (МР, НМд) } \\
\text { Закріплювати вміння диференціювати основні емоційні стани (радість - сум - } \\
\text { злість - страх) за зоровою опорою та вербальним описом. (ЕЦР, МР) } \\
\text { Уточнювати лексичне значення антонімів (гучно-тихо, швидко-повільно, весело-- } \\
\text { сумно). (МР) } \\
\text { Вправляти в інтонуванні окремих словосполучень, речень (розповідна, спону- } \\
\text { кальна, питальна інтонація). (МР, ЕЦР) } \\
\text { Заохочувати до співу дуетом, проспівування музичних діалогів. (ТМР, СКР) } \\
\text { Спонукати до імпровізації під час виконання вокальних вправ і музичних творів. (ТМР) } \\
\text { Виховувати бажання співати пісні з метою поліпшення (вираження) позитивного } \\
\text { настрою (ЕЦР) }\end{array}$ & 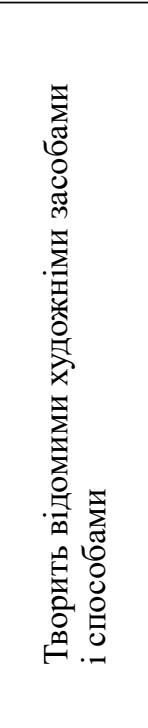 & 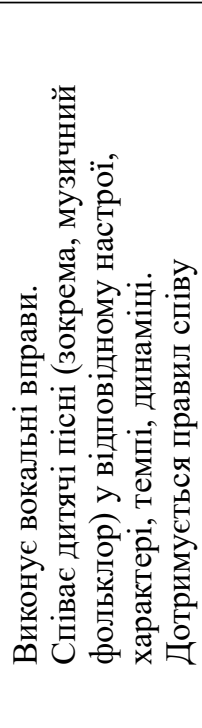 \\
\hline
\end{tabular}


вати, а також вміння діяти цілеспрямовано, усвідомлено, самостійно, прогнозуючи результат, визначати і досягати намічених навчальних цілей, у т. ч. за допомогою створення власного навчального середовища.

Простежимо, як на прикладі мистецької освітньої галузі практично реалізується викладене вище (див. табл. 3).

Стандартизація навчально-методичного забезпечення освіти дітей із тяжкими порушеннями мовлення грунтується на засадах психолінгвістичного, нейропсихологічного, дитиноцентричного, діяльнісного, диференційованого підходів, принципах науковості, інтегрованості, доступності та практичної спрямованості з метою полегшеної побудови індивідуальної траєкторії розвитку школяра. Організація та проведення освітнього процесу з поліморфною групою здобувачів початкової освіти з ТПМ потребує обов'язкового застосування індивідуального (вік, стать, інтереси, здібності, творчий потенціал), диференційованого та психолінгвістичного підходів (урахування форми, структури, ступеня складності мовленнєвого порушення), ефективна реалізація яких можлива за таких загальних умов: 1) систематичного виправлення в учнів, як в індивідуальних, так і колективних формах роботи, мовленнєвих помилок: а) фонетичних (це, переважно, свистячі, шиплячі та сонори); б) фонематичних (особливої уваги потребують ті слова/словосполучення, в яких наявні корелюючі звуки: наприклад, [c]-[ш], [л]-[р] тощо); в) лексичних (обов'язкове урахування лексичної валентності, тобто правильного змістового добору тієї чи іншої лексеми у словосполученні чи реченні); г) граматичних (нормативне узгодження іменників із прикметниками в роді, числі, відмінку, займенників із дієсловами відповідно до числа, роду, часу і виду); 2) дотримання інтегративної та мотиваційно-ігрової форми уроків, що передбачає обов'язкове психоемоційне розвантаження школярів; 3) розширення мовленнєво-пізнавального світогляду учнів, пізнання себе через різні види діяльності; 4) варіювання дидактичного, мовленнєвого, ігрового матеріалу, 3 актуалізацією раніше засвоєних знань, опорою на власний досвід, на основі навчально-ігрової та практичної діяльності; 5) проведення на початку уроку підготовчої роботи у вигляді різних видів ігор і вправ на удосконалення та розвиток зорових, слухових, мовленнєвих, мисленнєвих функцій та операцій, моторно-рухових та оптико-рухових навичок; 6) використання ряду методів: а) словесних - джерелом знань $є$ усне слово: емоційні та виразні вступні бесіди, пояснення, тлумачення, дискусії, попереджувальне, коментувальне, пояснювальне мовлення щодо послідовності роботи над малюнком чи виготовленням виробу, розповідь за результатами виконаної роботи, називання використаних технік і матеріалів, акцентоване промовляння найбільш складних у фонетичному плані термінів тощо; б) наочних, в яких джерелом знань виступають спостереження, конкретні предмети чи явища, роботи майстрів народних художніх промислів, твори мистецтва, малюнки, ілюстрації, репродукції, наочні посібники, муляжі, міні-моделі, схеми, алгоритми (детальні, покрокові, описові), кращі зразки дитячих робіт (ліплення, поробки з паперу, природного матеріалу) тощо; в) практичних методів, завдяки використанню яких учні отримують знання та здобувають уміння, виконуючи практичні дії у вигляді тренувальних, навчально-зображувальних, графічних, відтворювальних, ситуаційних вправ або навчально-продуктивної праці, мистецьких проектів, моделювання, дослідницької діяльності тощо); г) роботи з книгою - джерелом знань $\epsilon$ друковане слово - використання художньої літератури, підручників (читання, вивчення напам'ять, переказ прочитаного, складання плану 3 допомогою педагога, придумування невеличких розповідей з опорою на зразок, опорні слова); д) відео методів, у яких джерелом знань виступають мультимедійні презентації («електронний учитель») для вивчення (цілісного або демонстрації фрагментів) нового навчального матеріалу, його закріплення, здійснення поточного чи підсумкового контролю; 7) опанування школярами термінологією в усній (початковий-основний етапи) і писемній формах (заключний етап), на основі достатнього розуміння та використання попереднього гучного мовлення у вигляді цілісного, поскладового, акцентованого промовляння, 3 виокремленням складних для вимови дітей звуків, спряженого, відображеного, самостійного промовляння школярами, мовлення пошепки, складання речень $з$ вивченими словами, за можливості - добір синонімів чи антонімів, порівняння багатозначних слів, розрізнення паронімів, моделювання комунікативно-ігрових життєвих ситуацій; 8) дозованості та циклічності (багаторазове повторення у фонетичному - акцент на звуковому оформленні, графічному - на написанні, лексичному - на значенні, синтаксичному - на контекстуальному вживанні термінології; опора на вже раніше вивчений матеріал; перенесення набутих знань і навичок, способів діяльності на нову ситуацію); 9) алгоритмізованості навчальної діяльності (планування - поетапне осмис- 
лення (згорнутий чи розгорнутий план дій) та виконання в індивідуальному темпі - контроль iз застосуванням гучного, шепітного мовлення, мовлення подумки); 10) мультисенсорності, врахування інтегративної діяльності аналізаторів, міжпівкульної взаємодії, встановлення міжпредметних зв'язків; 11) використання різного виду опор: а) зорової - увага до зорового (предметного, графічного) матеріалу, наочний супровід, зоровий зразок, план-схема, предметно-інструкційна карта; б) слухової - акцент на слухове сприймання; в) кінетичної - динамічне виконання, руховий зразок, подальше перенесення на аналогічний матеріал, виконання по пам'яті, за уявленням; г) кінестетичної - статичне утримання, м'язові відчуття; д) вербальної - повторення інструкції, iї деталізація, пояснення, навідні запитання, передуюче, описове, коментувальне мовлення; е) емоційної - посмішка, погладжування по руці, голові, слова схвалення та підтримки; 12) створення відповідного предметного (комунікативного, технологічного) середовища для вільного, самостійного, різнопланового експериментування здобувачами освіти; 13) стимулювання учнів до прогнозування результатів, синтезу сформованих навичок у власній практичній діяльності, застосування навичок поточного та кінцевого контролю на смисловому, зоровому, слуховому та руховому рівнях, усний чи письмовий опис результатів проведеної роботи; 14) попередження появи вторинних відхилень у мовленнєвому (наприклад, невротичної форми заїкання на фоні загального недорозвитку мовлення нез'ясованого генезу) та пізнавальному розвитку; 15) виховної спрямованості (вміння «бачити і чути» іншого (-их), повага до нього (них), бажання прийти на допомогу в комунікативних і поведінкових ситуаціях, толерантність до наявних порушень психофізичного розвитку).

Репрезентовані нами рекомендації та зазначені загальні умови організації освітнього процесу допоможуть педагогам краще зрозуміти особливості психофізичного розвитку здобувачів початкової освіти з ТПМ, що значно підвищить результативність компенсаційної, розвивальної та психопрофілактичної роботи (Рібцун, 2018).

Висновки. Впровадження стандартизації початкової освіти дітей із тяжкими порушеннями мовлення в умовах Нової української школи потребує подальшого розроблення розгорнутих методичних рекомендацій за окремими освітніми галузями, які допоможуть не тільки учителям, психологам, працівникам інклюзивно-ресурсних центрів, а й батькам учнів зробити освітній процес цікавим, доступним, творчим, а головне - ефективним, комплексним та цілісним, компенсаційно спрямованим на виправлення первинних і запобігання вторинним порушенням психофізичного розвитку молодших школярів, формування їхньої життєвої компетентності, полегшення соціалізації, нормалізації комунікативної поведінки шляхом подолання наявних бар'єрів, удосконалення фонетичної, лексичної, граматичної, діалогічної, монологічної та комунікативної компетенцій.

\section{СПИСОК ВИКОРИСТАНИХ ДЖЕРЕЛ}

1. Про внесення змін до деяких законів України щодо доступу осіб з особливими освітніми потребами до освітніх послуг. Відомості Верхов. Ради Украӥни. К. : Парламентське вид-во, 2018. № 43. Ст. 345.

2. Про загальну середню освіту. URL: https://zakon.help/law/651-XIV/

3. Про затвердження Державного стандарту початкової освіти. URL: https://ru.osvita.ua/legislation/Ser_osv/59891/

4. Про затвердження Положення про інклюзивно-ресурсний центр. URL: http://zakon3.rada.gov.ua/laws/show/545$2017-\% \mathrm{D} 0 \% \mathrm{BF}$

5. Про схвалення Концепції реалізації державної політики у сфері реформування загальної середньої освіти «Нова українська школа» на період до 2029 року. URL: https:/www.kmu.gov.ua/ua/npas/249613934

6. Рібцун Ю. В. Стандартизація спеціальної дошкільної освіти дітей із порушеннями мовленнєвого розвитку. Науковий вісник Східноєвропейського національного університету імені Лесі Украӥнки. 2017. № 1 (350). С. 164-171.

7. Рібцун Ю. В. Комплексна психолого-педагогічна оцінка розвитку дітей з 2 до 18 років. Організаційно-методичні засади діяльності інклюзивно-ресурсних центрів. К., 2018. С. 149-156.

8. Рібцун Ю. В. Компоненти уроків в освітніх закладах для дітей із тяжкими порушеннями мовлення. Інноваційні наукові дослідження у галузі педагогіки та психології. Матеріали Всеукр. наук.-практ. конф. Запоріжжя : Класичний приватний університет, 2018. С. 160-163.

9. Рівні Національної рамки кваліфікацій. Відомості Верховної Ради. К. : Парламентське вид-во, 2017. № 38-39, ст. 380. URL: https://xn--80aagahqwyibe8an.com/download/zakon-ukrajini-pro-osvituvidomosti-verhovnoji2017-51849.html 


\section{REFERENCES}

1. Pro vnesennya zmin do deyakyx zakoniv Ukrayiny shhodo dostupu osib z osoblyvymy osvitnimy potrebamy do osvitnix posluh [On Amendments to Some Laws of Ukraine on the Access of Persons with Special Educational Needs to Educational Services]. Vidomosti Verxov. Rady Ukrayiny. K. : Parliamentary Publishing House, 2018. Nr 43. St. 345 [in Ukrainian].

2. Pro zahal'nu serednyu osvitu [About general secondary education]. URL: https://zakon.help/law/651-XIV/ [in Ukrainian].

3. Pro zatverdzhennya Derzhavnoho standartu pochatkovoyi osvity [On Approval of the State Standard of Elementary Education]. URL: https://ru.osvita.ua/legislation/Ser_osv/59891/ [in Ukrainian].

4. Pro zatverdzhennya Polozhennya pro inklyuzyvno-resursnyj centr [On Approval of the Regulations on the Inclusion and Resource Center]. URL: http://zakon3.rada.gov.ua/laws/show/545-2017- \%D0\%BF [in Ukrainian].

5. Pro sxvalennya Koncepciyi realizaciyi derzhavnoyi polityky u sferi reformuvannya zahal'noyi seredn'oyi osvity «Nova ukrayins'ka shkola» na period do 2029 roku [On Approval of the Concept for the Implementation of the State Policy in the Reform of General Secondary Education «New Ukrainian School» for the period up to 2029]. URL: https://www.kmu.gov.ua/ua/npas/249613934 [in Ukrainian].

6. Ribcun Yu. V. Standartyzaciya special'noyi doshkil'noyi osvity ditej iz porushennyamy movlennyevoho rozvytku [Standardization of special preschool education for children with speech development disorders]. Scientific herald of the Lesia Ukrainka Eastern European National University. 2017. Nr 1 (350). P. 164-171 [in Ukrainian].

7. Ribcun Yu. V. Kompleksna psyxoloho-pedahohichna ocinka rozvytku ditej z 2 do 18 rokiv [Comprehensive psychological and pedagogical assessment of the development of children from 2 to 18 years old]. Orhanizacijno-metodychni zasady diyal'nosti inklyuzyvno-resursnyx centriv. K., 2018. P. 149-156 [in Ukrainian].

8. Ribcun Yu. V. Komponenty urokiv u osvitnix zakladax dlya ditej iz tyazhkymy porushennyamy movlennya [Components of lessons at educational institutions for children with severe speech impairment]. Innovacijni naukovi doslidzhennya $u$ haluzi pedahohiky ta psyxolohiyi. Materialy Vseukr. nauk.-prakt. konf. Zaporozhye: Classic Private University, 2018. P. 160-163 [in Ukrainian].

9. Rivni Nacional'noyi ramky kvalifikacij [Levels of National Qualifications Framework]. Vidomosti Verxov. Rady Ukrayiny. K. : Parliamentary Publishing House, 2017. Nr 38-39, st. 380. URL: https://xn--80aagahqwyibe8an.com/download/ zakon-ukrajini-pro-osvituvidomosti-verhovnoji-2017-51849.html [in Ukrainian]. 